\title{
ミコフェノール酸モフェチルの全身性エリテマトーデスにおける有用性の検討
}

\author{
鈴木大介，小川法良，澤田＼cjkstart仁
}

木 本＼cjkstart理，下山久美子，林＼cjkstart秀晴

\section{The efficacy of mycophenolate mofetil for systemic lupus erythematosus}

\author{
Daisuke SuzUKI, Noriyoshi OGAWA, Jin SAwADA, \\ Osamu Kimoto, Kumiko SHImoYAMA and Hideharu HAYASHI
}

Hamamatsu University School of Medicine, Internal Medicine III

(Received March 19, 2009)

\begin{abstract}
summary
Systemic lupus erythematosus (SLE) is usually treated with corticosteroids and immunosuppressive agents. However, some patients are refractory to these agents, others show adverse effects. Usefulness of mycophenolate mofetil (MMF) in SLE has been reported in several studies. In this study, we evaluated the clinical efficacy and adverse effects of MMF in SLE. Sixteen cases which were difficult to reduce the dose of corticosteroid, resistant to immunosuppressive agents or could not use them for adverse effects were treated with MMF. Thirteen cases were females and three were males. Mean age was 44.4 \pm 9.2 year-old. Mean duration of SLE was 12.5 \pm 6.9 years. Mean observational duration was $12.0 \pm 5.5$ months. Mean maintenance dose of MMF was $1.95 \pm 0.61 \mathrm{~g} /$ day. Good clinical response was obtained in $69 \%$ of total cases. In laboratory data, serum $\operatorname{IgG}(\mathrm{p}<0.05)$ decreased and the levels of serum albumin $(\mathrm{p}<$ $0.01)$ and complement $(\mathrm{p}<0.05)$ increased significantly. Adverse effects, mainly infections, were observed, but severe infection was not experienced. This study suggests that MMF is effective and relatively safe for SLE.
\end{abstract}

Key words_-mycophenolate mofetil; systemic lupus erythematosus; efficacy

抄 録

全身性エリテマトーデス（SLE）に対してステロイド，免疫抑制剂が使用され，一定の効果が得られている。し かし，効果不十分例や副作用のためこれらの治療が十分行えない症例が存在する. 近年，ミコフェノール酸モフェ チル（MMF）が SLEに有効であると報告され，新たな治療の選択肢として注目が集まっている．本研究では，ス テロイド減量困難あるいは免疫抑制剂抵抗性を示した症例，または，副作用のためステロイドの継続投与が困難で あった全身性エリテマトーデス 16 症例を対象とし，ミコフェノール酸モフェチル（MMF）の投与を行い臨床的効 果，有害事象を評価した。16症例のうち，女性は 13 例 $(81 \%)$ ，男性は 3 例（19\%）であり，平均年齢は $44.4 \pm$ 9.2 歳, 平均罹病期間は $12.5 \pm 6.9$ 年であった. MMF と PSL の初期投与量はそれぞれ $1.44 \pm 0.51 \mathrm{~g}, 12.1 \pm 4.73$ $\mathrm{mg}$ であり維持量はそれぞれ $1.95 \pm 0.61 \mathrm{~g}, 9.8 \pm 3.35 \mathrm{mg}$ であった. MMFの平均投与期間は $12.0 \pm 5.5$ ヶであっ た．臨床的改善は $69 \%$ に認められ，臨床検査值では投与 6 ヶ月から有意な $\operatorname{IgG} の$ 低下，アルブミン，補体価の上 昇が認められた．有害事象は感染症が多かったが重篤なものはなかった．MMF は全身性エリテマトーデスに有効 で，比較的に安全に使用できる可能性が示唆された。

\section{はじめに}

全身性エリテマトーデスの治療は副腎皮質ステロ イドを基本とし，各種の免疫抑制剂が有効性の改善 と，ステロイドの減量を目的に使用される。ループ ス腎炎に関しては，ステロイド単独より，シクロフ ォスファミド（CPA）を併用する方が寛解率およ

浜松医科大学 第 3 内科
び腎生存率に優れることが示され1〜5)，標準的な治 療法となっている。しかし，シクロフォスファミド は，不妊，感染症，出血性膀胱炎，発癌のリスクと なり，より安全な治療法の確立が求められている. 近年, ミコフェノール酸モフェチル (MMF) がルー プス腎炎に用いられ，有効かつ比較的安全であると 報告されている6 10). 我々は, MMF を治療抵抗 性, 難治性の SLE に使用し，その効果，安全性を 評価した。 


\section{対象と方法}

\section{1. 対象患者}

1982 年のアメリカリウマチ学会 SLE 改訂分類基 準11)を満たす患者で，ステロイドが減量困難あるい は少なくとも 1 剂以上の免疫抑制剂に対して抵抗性 を示した症例，または，副作用のためステロイドの 継続投与が困難であった 16 症例を対象とした（表 1). 16 症例中，女性 13 例 $(81 \%)$ ，男性 3 例（19 \%) であり，平均年齢は $44.4 \pm 9.2$ 歳，平均罹病期 間は $12.5 \pm 6.9$ 年であった. SLEの臓器障害は, ループス腎炎 11 例, 中枢神経ループス 4 例 (うち, 一例はループス腎炎の合併)，間質性肺炎 2 例，溶 血性貧血 1 例であった。なお，本研究は，浜松医科 大学倫理審査委員会の承認を得て行われた.

\section{2. 投与方法と経過観察}

MMF を 6 力月以上投与し，効果ならびに有害事 象を評価した。平均投与期間は $12.0 \pm 5.5$ ヶ月（表 2) であった。 MMF の初期投与量は，疾患活動性
を考慮して決定し，1日 2 回分服とした。病勢なら びに忍容性を考慮し，投与量は 1 日 $3 \mathrm{~g}$ を上限に漸 増した。 MMFの減量 · 中止基準は，MMFによる 副作用にて, 減量 · 中止が必要と判断された場合, 明らかな SLEの活動性増悪により，無効と判断さ れた場合，6 ケ月以上抗 DNA 抗体正常化と血清補 体価正常化が達成され, かつ, 臨床症状と臓器障害 が確認できない場合, ならびに, 患者の減量・中止 希望があった場合とした。 ステロイドは可能な限り 減量を行った。

臨床症状, 腎以外の臓器障害, 抗 DNA 抗体, 血 清補体価, 尿蛋白, ステロイド量変化の 6 項目を改 善，不変，増悪で評価し，それぞれに $1,0,-1$ の スコアを与え， 6 項目の合計が 2 以上を改善， 1 か らー1 を不変， -2 以下を増悪と定義した。なお， 臨床検査值については投与前值に比して $50 \%$ 以上 の改善または増悪，もしくは，基準值と比べて投与 後に正常化または異常化した場合を改善と増悪とし た. ステロイドはプレドニゾロン $1 \mathrm{mg}$ 以上の増 量, 減量をそれぞれ改善, 増悪とした。また,

表 1 対象症例と治療歴

\begin{tabular}{|c|c|c|c|c|c|c|}
\hline No. & 性 & 年齢 & $\begin{array}{l}\text { 罹病期間 } \\
\text { (年) }\end{array}$ & 断 & $\begin{array}{c}\text { 直前の免疫抑制剤 } \\
\text { と変更理由 }\end{array}$ & その 他 \\
\hline 1 & $\mathrm{~F}$ & 43 & 15 & ループス腎炎, 間質性肺炎 & MZB 無効 & AZA, CY : 無効 CyA : 高血圧 \\
\hline 2 & $\mathrm{M}$ & 28 & 7 & ループス腎炎, APS & AZA 無効 & $\mathrm{CY}$ : 発熱 \\
\hline 3 & $\mathrm{~F}$ & 37 & 3 & ループス腎炎, Sjs & MZB 無効 & \\
\hline 4 & $\mathrm{~F}$ & 55 & 18 & ループス腎炎, Sjs & CyA 無効 & \\
\hline 5 & $\mathrm{M}$ & 58 & 3 & ループス腎炎 & AZA 無効 & IVCY, AZA：無効 CY：下痢 \\
\hline 6 & $\mathrm{~F}$ & 49 & 15 & ループス腎炎 & AZA 無効 & MZB : 無効 \\
\hline 7 & $\mathrm{~F}$ & 43 & 24 & ループス腎炎 & $\begin{array}{l}\text { MZB 無効 } \\
\text { 肝機能障害 }\end{array}$ & \\
\hline 8 & $\mathrm{M}$ & 48 & 6 & ループス腎炎 & AZA 無効 & \\
\hline 9 & $\mathrm{~F}$ & 45 & 14 & ループス腎炎 & MZB 無効 & IVCY：無効 \\
\hline 10 & $\mathrm{~F}$ & 34 & 10 & ループス腎炎, 膵炎 & MZB 無効 & \\
\hline 11 & $\mathrm{~F}$ & 50 & 24 & ループス腎炎, 中枢神経ループス & MZB 無効 & \\
\hline 12 & $\mathrm{~F}$ & 44 & 15 & 中枢神経ループス & AZA 無効 & \\
\hline 13 & $\mathrm{~F}$ & 34 & 16 & 中枢神経ループス & AZA 白血球減少 & $\mathrm{CY}$ : 発熱 \\
\hline 14 & $\mathrm{~F}$ & 33 & 3 & 中枢神経ループス, 肺高血圧 & MZB 無効 & \\
\hline 15 & $\mathrm{~F}$ & 52 & 18 & SLE, 間質性肺炎, Sjs & CyA 腎機能障害 & $\mathrm{CY}$ : 発熱 $\mathrm{AZA}$ : 肺炎 $\mathrm{MZB}$ : 無効 \\
\hline 16 & $\mathrm{~F}$ & 58 & 10 & SLE, 自己免疫性溶血性貧血 & AZA 無効 & \\
\hline 平均 & & $44.4 \pm 9.2$ & $12.5 \pm 6.9$ & & & \\
\hline
\end{tabular}

APS : antiphospholipid antibody syndrome, Sjs : Sjogren's syndrome, SLE : systemic lupus erythematosus, MZB : mizoribine, AZA : azathioprine, CyA : cyclosporin A , CY : cyclophosphamide, IVCY : intravenous cyclophosphamide 
表 2 MMF ならびに PSL 投与量の推移

\begin{tabular}{|c|c|c|c|c|c|}
\hline No. & MMF 初期量 (g/日) & MMF 維持量 $(\mathrm{g} /$ 日) & PSL 初期量 (mg/日) & $\mathrm{PSL}$ 維持量 $(\mathrm{mg}$ /日) & 投与期間 (月) \\
\hline 1 & 0.5 & 3 & 15 & 11 & 24 \\
\hline 2 & 2.5 & 2.5 & 5 & 5 & 21 \\
\hline 3 & 1 & 2 & 10 & 10 & 17 \\
\hline 4 & 1 & 2.5 & 20 & 7.5 & 17 \\
\hline 5 & 1 & 2.5 & 7.5 & 18 & 16 \\
\hline 6 & 1.5 & 1.5 & 10 & 10 & 12 \\
\hline 7 & 1.5 & 2 & 15 & 7.5 & 10 \\
\hline 8 & 2 & 2 & 12.5 & 11 & 7 \\
\hline 9 & 2 & 2.5 & 20 & 12.5 & 7 \\
\hline 10 & 1.5 & 2.25 & 8 & 8 & 6 \\
\hline 11 & 1 & 1 & 10 & 10 & 9 \\
\hline 12 & 1.5 & 1 & 12.5 & 8 & 12 \\
\hline 13 & 1 & 1.5 & 15 & 10 & 10 \\
\hline 14 & 1.5 & 2 & 20 & 5 & 10 \\
\hline 15 & 1.5 & 2 & 10 & 9 & 8 \\
\hline 16 & 2 & 1 & 7.5 & 15 & 6 \\
\hline 平均 & $1.44 \pm 0.51$ & $1.95 \pm 0.61$ & $12.1 \pm 4.73$ & $9.8 \pm 3.35$ & $12.0 \pm 5.5$ \\
\hline
\end{tabular}

SLEDAI ${ }^{11) ~(S y s t e m i c ~ L u p u s ~ E r y t h e m a t o s u s ~ D i s e a s e ~}$ Activity Index）を投与前後で比較した。

統計

すべての結果は平均土標準偏差で表し, 統計学的 解析は対応のある $\mathrm{t}$ 検定を用いた。

\section{結果}

\section{MMF と PSL (prednisolone) の投与量の推移}

MMF と PSLの初期投与量はそれぞれ $1.44 \pm$ $0.51 \mathrm{~g}, 12.1 \pm 4.73 \mathrm{mg}$ であり維持量はそれぞれ 1.95 $\pm 0.61 \mathrm{~g}, 9.8 \pm 3.35 \mathrm{mg}$ であった（表 2). PSL の平 均投与量は減少したが，有意差を認めなかった（p $=0.19) .1 \mathrm{mg} /$ 日以上のステロイド減量例は 9 例 $(56 \%)$, 不変症例は 5 例 $(31 \%), 1 \mathrm{mg} /$ 日以上の ステロイド増加症例 2 例 $(13 \%)$ であった。

\section{2. 有効性}

臨床的効果に関しては，今回，我々が用いた判定 基準では，改善 11 例 $(69 \%)$ ，不変 4 例 $(25 \%)$, 増悪 1 例 $(6 \%)$ であった。主な効果は血清補体価 の上昇，抗 DNA 抗体の低下であった（表 3 ）. SLEDAI に関しては投与前 $6.3 \pm 3.0$ であったが投 与後 $3.3 \pm 2.9$ と有意な $(\mathrm{p}<0.01)$ 低下を認めた. 臨床検査值（表 4）は投与前に比して投与 6 力月
後より有意な血清アルブミン, 血清補体価上昇, 血 清 IgG の低下が認められた。抗 DNA 抗体につい ても投与 6 力月後以降, 低下の傾向があった。

\section{3. 有害事象}

有害事象は延べ 20 事象認められ，16 症例中 13 例 $(81 \%$ ) に認めた（表 5). 認められた有害事象 は，すべて感染症であり，上気道炎 13 事象，腸炎 4 例, 膿皮症 1 例, インフルエンザ 1 例, 口腔カン ジダ症 1 例であった. MMF の中止に至る重篤な感 染症は認められなかった。

\section{考察}

SLE に対する免疫抑制剤として，シクロフォス ファミドの有効性が確立している1 5). しかし, 発 癌性, 不妊, 出血性膀胱炎などの重大な有害事象も 多く, 課題もある. シクロスポリン $\mathrm{A}^{11 \sim 15)}$, ミゾ リビン16)，アザチオプリン ${ }^{17,18)}$ も有効性を示す報告 があり，シクロフォスファミドの使用できない症例 やシクロフォスファミド後の寛解維持に用いられる.

近年, ミコフェノール酸モフェチル（MMF）の SLE に対する有効性を示す報告が海外を中心に相 次いでいる6 10). MMF は経口投与すると消化管に おいて吸収され循環血液中に到達する過程で活性体 
表 3 臨床効果

\begin{tabular}{cccccl}
\hline \hline No. & スコア & 効果 & SLEDAI(前) & SLEDAI(後) & 備 \\
\hline 1 & 2 & 改善 & 4 & 2 & 抗 DNA 抗体·補体正常化, 間質性肺炎軽快, 尿潜血改善 \\
\hline 2 & 2 & 改善 & 4 & 4 & 抗 DNA 抗体低下, 補体正常化, 血清アルブミン上昇 \\
\hline 3 & 3 & 改善 & 8 & 2 & 抗 DNA 抗体正常化, 補体上昇, 尿蛋白減少 \\
\hline 5 & 2 & 改善 & 8 & 4 & 尿蛋白減少 \\
\hline 6 & 0 & 不変 & 2 & 12 & 抗 DNA 抗体上昇, 尿蛋白増加 \\
\hline 7 & 2 & 改善 & 8 & 2 & \\
\hline 8 & 2 & 改善 & 12 & 4 & 抗 DNA 抗体低下, 関節痛·発熱改善 \\
\hline 9 & 2 & 改善 & 9 & 8 & 補体価上昇 \\
\hline 10 & 0 & 不変 & 6 & 4 & 抗 DNA 抗体·補体正常化 \\
\hline 11 & 2 & 改善 & 8 & 2 & \\
\hline 12 & 0 & 不変 & 2 & 2 & 補体上昇 \\
\hline 13 & 2 & 改善 & 2 & 2 & \\
\hline 14 & 2 & 改善 & 8 & 0 & 抗 DNA 抗体正常化 \\
\hline 15 & 2 & 改善 & 4 & 6 & 抗 DNA 抗体低下, 補体正常化 \\
\hline 0 & 不変 & 6 & 4 & 抗 DNA 抗体低下 \\
\hline
\end{tabular}

表 4 臨床検査值の推移

\begin{tabular}{lccc}
\hline \hline \multicolumn{1}{c}{ 検 査 值 } & 投与前 & 6 ヶ月後 & 12 ヶ月後 \\
\hline 尿蛋白 $(\mathrm{g} /$ 日 $)$ & $0.56 \pm 0.63$ & $0.40 \pm 0.6$ & $0.41 \pm 0.46$ \\
\hline 血清クレアチニン $(\mathrm{mg} / \mathrm{dl})$ & $0.62 \pm 0.13$ & $0.62 \pm 0.14$ & $0.61 \pm 0.12$ \\
\hline 血清アルブミン $(\mathrm{g} / \mathrm{dl})$ & $3.74 \pm 0.41$ & $3.93 \pm 0.40^{* *}$ & $4.03 \pm 0.35^{* *}$ \\
\hline 血清 $\mathrm{IgG}(\mathrm{mg} / \mathrm{dl})$ & $1426 \pm 413$ & $1209 \pm 280^{*}$ & $1218 \pm 250^{*}$ \\
\hline リンパ球数 $(/ \mu \mathrm{l})$ & $906 \pm 433$ & $846 \pm 406$ & $908 \pm 442$ \\
\hline 抗 $\mathrm{DNA}$ 抗体 $(\mathrm{U} / \mathrm{ml})$ & $49 \pm 73$ & $18 \pm 22$ & $18 \pm 24$ \\
\hline $\mathrm{CH} 50(\mathrm{U} / \mathrm{ml})$ & $31.4 \pm 14.9$ & $43.4 \pm 12.5^{* *}$ & $40.0 \pm 11.0^{*}$ \\
\hline$* p<0.05, * * p<0.01(\mathrm{vs}$ 投与前値 $)$ & & &
\end{tabular}

のミコフェノール酸（MPA）となる。MPA は肝 臓でグルクロン酸抱合を受け，非活性体となり一部 が腸管循環をする．MPA は de novo プリン合成に おけるイノシンモノ燐酸脱水素酵素を阻害し，リン パ球の増殖を抑制する。活性化 $\mathrm{T}$ 細胞のアポトー シス誘導, $\mathrm{B}$ 細胞の抗体産生抑制, 酸素ラジカルや 接着因子の発現抑制も認められている ${ }^{19 \sim 21)}$.

本研究では，既存の免疫抑制剂が使用しがたい， または，無効である症例，もしくは，ステロイド療 法に抵抗性を示すSLE 症例に MMF を投与し，そ の効果と有害事象の検討を行ったものである. MMF の初期投与量は平均 $1.4 \mathrm{~g}$ であるが，有害事
象やSLE の活動性を考慮し維持量は平均 $1.95 \mathrm{~g}$ ま で増量されている. 減量されたのは 16 例中 2 例で あったが，有害事象による減量ではなかった。維持 量として約 $70 \%$ 症例は $2 \mathrm{~g}$ 以上が必要であった。 逆に, 維持量として $3 \mathrm{~g}$ を使用した症例は 1 例で, 多くは $3 \mathrm{~g}$ 未満で効果が認められた。腎移植後の拒 絶反応の抑制には，2３ $\mathrm{g}$ が使用されており，SLE に対してもこの用量の範囲で臨床効果が期待でき る. 初期投与量の増量が理想的だが，保険適応外で あること，薬価が高いことを考慮し，現時点では， 漸増し維持量を決定する方法が，現実的である. 1 $\mathrm{mg} /$ 日以上のステロイド減量は $56 \%$ の症例で達成 
表 5 有害事象

\begin{tabular}{cc}
\hline \hline No. & 有害事象 \\
\hline 1 & 上気道炎 $(2$ 回 $)$ \\
\hline 2 & 上気道炎 \\
\hline 3 & 上気道炎 \\
\hline 4 & なし \\
\hline 5 & 上気道炎 \\
\hline 6 & 膿皮症 \\
\hline 7 & 上気道炎, インフルエンザ \\
\hline 8 & 上気道炎, ロ腔カンジダ症 \\
\hline 9 & なし \\
\hline 10 & 上気道炎, 腸炎 \\
\hline 11 & なし \\
\hline 12 & 上気道炎, 腸炎 \\
\hline 13 & 上気道炎 \\
\hline 14 & 上気道炎 $(2$ 回 $)$ \\
\hline 15 & 腸炎 $(2$ 回 $)$ \\
\hline 16 & 発熱 \\
\hline
\end{tabular}

され，増加例は $13 \%$ と比較的少なかった．ステロ イド平均投与量には MMF 投与前後で, 統計学的 な差を見出すことはできなかったものの，個々の症 例ではステロイド減量例が半数を占めること, 平均 投与量は減少していることから，本研究の症例が難 治例であることも考慮すると，MMF にステロイド 減量効果がある可能性がある. 統計的有意差を見出 せなかった理由に，観察期間の短さがあると考えら れ，更に観察期間延長して平均投与量の比較を行う 必要がある。臨床検査值に関しては，血清アルブミ ン及び補体上昇， $\operatorname{IgG}$ の有意な低下が認められ，抗 DNA 抗体低下傾向が認められた．これらの変化も 難治例でかつステロイド減量例が多いなかで達成さ れて打り MMFの有用性を示すものと考えられ る. 全般的な効果として改善は約 7 割に認められ， 投与前後の SLEDAI の有意な低下も認められた。 増悪例はループス腎炎（WHO-II）の症例で, PSL7.5 mg と MMF1 $\mathrm{g}$ で開始され，12 ヶ月の時点 でMMF2 g としたが，抗 DNA 抗体の更なる上昇 が認められ，ステロイド増量が行われ増悪と判断し た。

有害事象としては，感染症が多かったが，重篤な 感染症はなかった．ステロイド使用量が多いことも 影響していると考えられるが感染症には十分な注意
が必要であると考えられた。本観察期間中に肝障 害, 腎障害, 骨髄抑制等は認めなかった。 悪性腫瘍 の発現などより長期的な有害事象については検討の 余地があると考えられる。

\section{結論}

本研究は少数例かつコントロール群がない研究で あるが，69\%の症例で改善を認め, 増悪したものは 6\%にとどまった。有害事象は感染症が最も多い が，重篤なものはなく，投与中止に至ったものはな かった. MMF はSLE 治療においてシクロフォス ファミドと同等の有効性を持ち, より安全である可 能性があり，本邦においても症例の蓄積ならびに有 効性, 有害事象の検討を今後更に進めていく必要が あると考える。

\section{文献}

1) Austin, H. A., 3rd, et al.: Therapy of lupus nephritis. Controlled trial of prednisone and cytotoxic drugs. N Engl J Med, 314(10): 614619, 1986.

2) Boumpas, D. T., et al.: Controlled trial of pulse methylprednisolone versus two regimens of pulse cyclophosphamide in severe lupus nephritis. Lancet, 340 (8822): 741-745, 1992.

3) Gourley, M. F., et al.: Methylprednisolone and cyclophosphamide, alone or in combination, in patients with lupus nephritis. A randomized, controlled trial. Ann Intern Med, 125 (7): 549557, 1996.

4) Illei, G. G., et al.: Combination therapy with pulse cyclophosphamide plus pulse methylprednisolone improves long-term renal outcome without adding toxicity in patients with lupus nephritis. Ann Intern Med, 135(4): 248-257, 2001.

5) Steinberg, A. D. and S. C. Steinberg: Longterm preservation of renal function in patients with lupus nephritis receiving treatment that includes cyclophosphamide versus those treated with prednisone only. Arthritis Rheum, 34 (8): 945-950, 1991.

6) Buratti, S., et al.: Mycophenolate mofetil treatment of severe renal disease in pediatric onset systemic lupus erythematosus. J Rheumatol, 28 (9): 2103-2108, 2001.

7) Ginzler, E. M., et al.: Mycophenolate mofetil or intravenous cyclophosphamide for lupus 
nephritis. N Engl J Med, 353(21) : 2219-2228, 2005.

8) Chan, T. M., et al.: Long-term study of mycophenolate mofetil as continuous induction and maintenance treatment for diffuse proliferative lupus nephritis. J Am Soc Nephrol, 16(4): 1076-1084, 2005.

9) Kapitsinou, P. P., et al.: Lupus nephritis: treatment with mycophenolate mofetil. Rheumatology (Oxford), 43 (3): 377-380, 2004.

10) Dooley, M. A., et al.: Mycophenolate mofetil therapy in lupus nephritis: clinical observations. J Am Soc Nephrol, 10(4): 833-839, 1999.

11) Bombardier, C., et al.: Derivation of the SLEDAI. A disease activity index for lupus patients. The Committee on Prognosis Studies in SLE. Arthritis Rheum, 35(6): 630-640, 1992.

12) Tan, E. M., et al.: The 1982 revised criteria for the classification of systemic lupus erythematosus. Arthritis Rheum, 25 (11): 1271-1277, 1982.

13) Caccavo, D., et al.: Long-term treatment of systemic lupus erythematosus with cyclosporin A. Arthritis Rheum, 40(1): 27-35, 1997.

14) Sugiyama, M., et al.: Effect of extremely low dose cyclosporine treatment on the thrombocytopenia in systemic lupus erythematosus. Lupus, 7 (1): 53-56, 1998.

15) Tam, L. S., et al.: Long-term treatment of lu- pus nephritis with cyclosporin A. QJM, $91(8)$ : 573-580, 1998.

16) Yumura, W., et al.: Effects of long-term treatment with mizoribine in patients with proliferative lupus nephritis. Clin Nephrol, 64(1): 2834, 2005.

17) Contreras, G., et al.: Maintenance therapies for proliferative lupus nephritis: mycophenolate mofetil, azathioprine and intravenous cyclophosphamide. Lupus, 14(Suppl 1): 33-38, 2005.

18) Mok, C. C., et al.: Treatment of pure membranous lupus nephropathy with prednisone and azathioprine: an open-label trial. $A m J$ Kidney Dis, 43 (2): 269-276, 2004.

19) Allison, A. C. and E. M. Eugui: Mycophenolate mofetil and its mechanisms of action. Immunopharmacology, 47 (2-3) : 85-118, 2000.

20) Eugui, E. M., A. Mirkovich, and A. C. Allison: Lymphocyte-selective antiproliferative and immunosuppressive effects of mycophenolic acid in mice. Scand J Immunol, $33(2)$ : 175-183, 1991.

21) Eugui, E. M., et al.: Lymphocyte-selective cytostatic and immunosuppressive effects of mycophenolic acid in vitro: role of deoxyguanosine nucleotide depletion. Scand J Immunol, 33 (2) : 161-173, 1991. 